\title{
Price Elasticity of Demand for Pipe-Borne Water: A Pre- Requisite for Solving the Water Problem in the Colombo City
}

\section{Roshen Fernando ${ }^{*}$, SP Premaratne ${ }^{2}$}

1,2Department of Economics, University of Colombo, Colombo 3, Sri Lanka

\section{Abstract}

Water problem in the Colombo city has aggravated over the time. Thus, encouraging consumers for responsible water consumption is imperative. As the city is almost completely reliant on pipe-borne water, water tariff could be utilized in this effort. However, as water is a basic need and a human right, an upward revision of tariff should not deprive consumers from satisfying essential needs, while discouraging wasteful consumption. Therefore, this study attempted to identify whether the consumers are sensitive to changes in water tariff, whether there exists a disparity among different blocks of tariff with respect to Price Elasticity of Demand and identify different sensitivities of levels of consumption to an increase in tariff.

In order to achieve the research objectives, the Price Elasticity of Demand for pipe-borne water, overall and block-wise, was analyzed, before and after the last revision of tariff in 2012. Results revealed that after the revision, overall consumption had reduced and out of nine blocks, first three and last two were the least sensitive and the

*Correspondence should be addressed to Mr. Roshen Fernando. Department of Economics, University of Colombo.

Email: wbrpsfdo@gmail.com

https://orcid.org/0000-0001-5245-6702

(Received 20th October 2017; Revised 10th March 2018; Accepted 08th May 2018) @ OUSL

\section{cc) (7) (2)}

This article is published under the Creative Commons Attribution-Share Alike 4.0 International License (CC-BY-SA). This license permits use, distribution and reproduction in any medium; provided it is licensed under the same terms and the original work is properly cited. 
four blocks in the middle were the most sensitive. Thus, it was recommended that in order to discourage wasteful consumption, unit rates of highly sensitive blocks should be increased and to preserve economic efficiency and welfare, the tariff for least sensitive blocks should not be revised significantly.

Keywords: Price Elasticity of Demand, Pipe-borne Water, Water Tariff, Domestic Consumers

\section{Introduction}

The water problem in the Colombo city, the commercial capital of Sri Lanka, has been created by rapid urbanization, increase in population, change in climatic conditions, problems related to operational efficiency and increased pollution and depletion of water sources. This has, in turn, resulted in several issues, including those related to health and sanitation and water stress in the city. As the Colombo city continues to develop and become a strategic hub for Asia, it is of utmost importance to combat the water problem. As the Colombo city is almost covered with pipe-borne water, one of the major solutions to reduce the magnitude of the problem is to encourage consumers to use the resource responsibly, via awareness raising and revision of tariff.

Moreover, an upward revision of tariff would also enable National Water Supply \& Drainage Board (NWSDB), the main authority instrumental in provision of water for the Colombo city, to increase its operational income and reduce reliance on government grants and soft loans. Furthermore, this would enable NWSDB improve its service, reducing operational inefficiencies.

However, due to socio-economic and political sensitivities attached to water, a revision in tariff is, generally, heavily resisted by the society and could lead to social unrest. Thus, prior to revision of tariff, it is of utmost importance to understand which levels of consumption are more sensitive to changes in price, thus, indicative of wasteful or preventable consumption, and which levels of consumption are less sensitive to changes in price, thus, indicative of essential consumption. Additionally, this would help achieve the broader goals 
of tariff revision, such as encouraging responsible use of the resource and preserving economic efficiency and welfare.

Nevertheless, it was observed that the recent attempt of NWSDB to revise tariff was heavily opposed by the masses, largely due to the absence of evidence as to how the revision has been formulated. Thus, had a study of this nature been performed, the justification for revision would have been made stronger. Considering the necessity of such research, this study was conducted to establish whether the demand for pipe-borne water in the Colombo city is responsive to changes in tariff, if it is responsive, whether there is a disparity among the blocks of consumption with respect to Price Elasticity and if there exists a disparity, which blocks of consumption are more or less responsive to changes in price.

\section{Review of Literature}

\section{Price Discrimination}

According to Niels et al. (2011), price discrimination is pricing the same product differently even though the price differentials do not reflect any cost differential. The most frequently-used classification of price discrimination has three types, referred to as first, second and third-degree price discrimination. Exploiting the maximum Willingness to Pay of each individual customer is referred to as firstdegree price discrimination; charging differently for different quantities consumed is referred to as second-degree price discrimination and different customer segments being charged differently is referred to as third-degree price discrimination (Cabral, 2005).

\section{Water Tariff Structures}

\section{Objectives of Water Tariff}

According to Boland \& Whittington (2000), water tariff should ensure revenue sufficiency for the service provider, economic efficiency for the users, equity and fairness, income redistribution and resource conservation. Additionally, Rogers et al. (2002) emphasizes on holistic sustainability as an important objective of water tariff. 


\section{Design of Water Tariff Structures}

According to Brannon (2017), the choice of a tariff structure is dependent upon factors including water availability, income of the consumers, intended purpose and levels of usage and socio-economic situations.

An ultimate structure could be inducing uniform charges, block, seasonal, peak, conservation or capacity rates. The commonly-used structures incorporate two-part tariff structure, where both flat and volumetric rates would be present.

The widely-used volumetric tariff structures would include a purely proportional component to the consumption and either increasing or decreasing block tariffs with variable or fixed bands.

\section{Water Problem}

According to Department of Interior, United States (1966), a water problem is essentially a concern about not having the adequate quantity of water of adequate quality, at a reasonable cost, when and where needed. According to this definition, few reasons for a water problem can be identified. If either water is not obtained in adequate quantity, quality at the right time and place or even if the price charged for water or cost borne in obtaining water is not affordable, then, there deemed to be a water problem.

According to NWSDB (2017), in assessing the quality of pipe-borne water there are two components considered as product and service components. The product component includes parameters, such as the quality of water received by a consumer, quantity of water demanded and received by the consumer, timely receipt of water and adequate pressure with respect to water received. The service component includes parameters, such as timely receipt of accurate bills, timely update of accounts, convenience of payments, advance and adequate notice of interruptions and productive responses to complaints.

Thus, combining both the definition of water problem and parameters of quality of pipe-borne water, it can be stated that absence of any of the product or service parameters will result in a water problem for consumers, depending on pipe-borne water provided by NWSDB. 


\section{Water Problem in the Colombo City: Nature, Causes and Consequences}

According to the Department of Census and Statistics (DOCS) Sri Lanka (2015), the population in the Colombo city is 561,314 . However, being the commercial capital of Sri Lanka, it records a much higher total population due to the daily mobile population approximated at 1.9 million (Ministry of Megapolis and Western Development, 2017). According to NWSDB (2017), the Colombo city is almost totally covered with pipe-borne water. However, still a number of water problems are faced by the population in the Colombo city (Bandara, 2003).

According to Letchumanamohan (2014), the problems faced by the consumers in the Colombo city with respect to obtaining of pipeborne water include insufficient pressure in the pipe distribution system, non-availability of water for 24 hours, inaccurate meter reading, delays in attending to repair work and poor quality of repairs leading to constant interruptions and leakages. Accordingly, it can be observed that these conditions satisfy the determinants of water problem and thus, it can be deemed that there exists a water problem faced by existing consumers in the Colombo city.

In addition to the water problem from the perspective of existing consumers, there exist few broader water problems for the Colombo city on the whole. According to Fernando (2014), non-revenue water in the Colombo city accounts approximately to $54 \%$ of the provision, and it hence, prevents the authority obtaining the right revenue and threatens the financial sustainability of the provision.

Furthermore, according to Gamini (2015) and Bandara (2003), increased pollution of water resources, such as those caused by industrial and domestic effluents, create critical challenges for NWSDB to provide water of the right quality demanded by the consumers and stipulated by World Health Organization continuously. Additional purification of water has resulted in additional costs for the authority, in turn compromising its financial sustainability. In situations where NWSDB has not been able to totally contain the damages, the risks to health of consumers have risen. 
In addition to that, according to Warakapitiya and Shankar (2017), excessive consumption of water by the ongoing construction projects in the Colombo city has led to reduction in pressure and quantity available for consumption by other existing consumers.

Moreover, according to Lanka Business Online (2017), the combination of climatic changes leading to dry weather and increase in population has led to an overall increase of $15 \%$ in water consumed by existing consumers in the Colombo city, making it further challenging for NWSDB to secure the right quantity and provide water throughout at the right pressure. The increased administration and other related charges have not been covered by the price charged, and accordingly, the service is not any longer financially sustainable for NWSDB.

In a much broader sense, the water problem in the Colombo city and Sri Lanka, on the whole, has been created by rapid urbanization, water scarcity and degradation, absence of inter-sector governance, lack of operational efficiency, lack of investment in the water sector and absence of incentivizing tariff structure for water conservation. These, in aggregate, have led to a number of problems, including inability to provide the right quantity of water of the right quality at the right price and time and maintaining the right service level, and have created a water problem in the Colombo city (Fan, 2016).

Due to the water problem in the Colombo city, a number of consequences, such as spreading of both water-borne and water vector habitat diseases, overall decline in sanitation of the population and risk of NWSDB not being financially viable have arisen (Fan, 2016).

\section{Potential Solutions for the Water Problem in the Colombo City}

Fan (2016) has proposed increasing operational efficiency, encouraging consumers to conserve water, increasing monitoring and regulation in order to prevent pollution of water resources, improving water sector governance and increasing investments in water sector and increasing financial sustainability of NWSDB in order to address the causes of the water problem. 


\section{Why Revision of Tariff \& Price Elasticity of Demand?}

According to the potential solutions, proposed by Fan (2016), one of the ways of addressing the water problem in the Colombo city is ensuring that NWSDB has sufficient financial and non-financial resources to cater to the demand for pipe-borne water fully without interruptions. In order to achieve this, while the government could empower NWSDB via grants, NWSDB too can utilize its tariff structures to obtain a cost-reflective charge from consumers. The current practice is to cover the operation and maintenance cost, in whole, and part of the investment cost, via a two-part, increasing block tariff scheme (NWSDB, 2017). This implies that with the rising operational and maintenance costs the tariff structure needs to be revised.

Moreover, one of the objectives of the utility tariff structures is to encourage consumers to use the utility responsibly and conserve it (Rajput, 2007). This objective would not be achieved if the tariff levied falls to an insignificant percentage of total disposable income of a consumer (Feenstra and Taylor, 2008). Accordingly, it is observed that the tariff structure needs to be revised from time to time to an acceptable level, without compromising the economic efficiency, to encourage consumers to preserve water.

NWSDB implemented its last tariff structure revision in October 2012. It is now underway to revise the tariff structure again to reflect the service level (NWSDB, 2017). However, the proposal to revise tariff structure is heavily opposed by the consumers and society, due to the concerns related to loss of economic efficiency and affordability. Two tools that could have been utilized in this effort to ensure perseverance of economic efficiency and affordability are an affordability analysis and a demand elasticity analysis with respect to price. Especially, an assessment of price elasticity of demand would enable to identify the level of consumption essential for consumers and levels of wasteful consumption, as with increase in price, a potential deviation towards conservation can be expected (Bishop and Weber, 1996). 


\section{Previous Methodologies}

Conley (1967) in Southern California for multiple sources; Katzman (1977) in Penang, Malaysia for domestic water; and Cairncross and Kinnear (1992) in Khartoum, Sudan for domestic water had established the price elasticity of demand for water using time series data. Young (1973), too, had assessed the price elasticity of demand for municipal water in Tucson, Arizona using statistical techniques and attempted to predict the changes in demand with changes in price using regression analysis.

Howe (1982), however, had established the Price Elasticity of Demand for residential water in different seasons using a consumer theory. Stevens et al. (1992) established the effect of price structure on residential water demand in Massachusetts for increasing block rate structure. Moreover, Olmstead et al. (2007) too established the price elasticity of demand using household consumption data for increasing block tariff structures.

Nevertheless, Thomas and Syme (1988) had adopted a contingent valuation approach in assessing the price elasticity of demand for groundwater as well as public supply of water for households in Perth, Western Australia.

\section{Research Gaps}

According to the literature review conducted, it was observed that encouraging consumers to be more mindful about consumption of pipe-borne water via a revision of tariff structure will be a feasible solution to reduce the water stress in the Colombo city. Moreover, it would help NWSDB, be more financially sustainable. However, prior to a revision of the tariff structure, identifying the price elasticity of demand and more and less responsive blocks of consumption would enable the implementation of a more effective and socially acceptable tariff revision. In assessing the price elasticity of demand time series analysis can be used, as it has proved to be successful in assessing Price Elasticity of Demand for increasing block tariff structures.

\section{Methodology}

\section{Research Design}

This study, first, attempted to establish whether the demand for pipeborne water among domestic consumers in the Colombo city is 
responsive to changes in tariff levied. Then, it attempted, depending upon its responsiveness, to identify whether there existed a disparity among the blocks of consumption with respect to price elasticity of demand, and thereby to identify which blocks of tariff were more and less responsive to changes in price. Thus, the study would be exploratory in nature (Creswell and Clark, 2011).

\section{Sampling Design}

\section{Population}

As the domestic consumer density in the Colombo city is much higher than the other parts of the country, with the expectation of adequate and uniform sampling, the population chosen for the study was the domestic consumers depending on pipe-borne water in the Colombo city, Sri Lanka.

\section{Sampling Method}

The pipe-borne water provision in the Colombo city is, first, divided into two divisions, as the Colombo City South and Colombo City North, and thereafter, further sub-divided into four area engineers' zones as Borella, Mattakkuliya, Kirulapone and Fort. From them, the Colombo City South, as the division and Fort, as the area engineers' zone were chosen for the study, as the highest residential consumer density was observed in Fort area engineers' zone. Therefore, from Fort, 200 domestic consumers were selected using simple random sampling. It was assumed that the consumer group chosen was fairly homogenous with respect to socio-economic characteristics, due to the large middle-income population living in the area.

\section{Data Collection Process of the Study}

The monthly consumption of pipe-borne water by 200 domestic consumers, attached to Fort area engineer's office, was obtained from the same, for a period of nine (09) months, before and after, the revision of tariff structure in October 2012.

In addition to them, the tariff structures for domestic consumers, before and after, the revision were obtained from NWSDB, in order to facilitate calculation of Price Elasticity of Demand for consumers of the Colombo city. 


\section{Statistical Analysis Design}

The statistical measures of central tendency, mean, median and mode, and the statistical measures of dispersion, range, variance and standard deviation, were utilized for the statistical analysis. Microsoft Excel and Statistical Package for Social Sciences (SPSS) were used to facilitate analysis purposes. The detailed analysis plan is depicted in Table 1 .

Table 1: Summary of Statistical Methods \& Tools

\begin{tabular}{ll}
\hline \multicolumn{1}{c}{ Method } & \multicolumn{1}{c}{ Tools } \\
\hline \multirow{2}{*}{ Descriptive Statistics } & $\begin{array}{l}\text { Frequency Distributions, } \\
\text { Graphs, Measures of, Central } \\
\text { Tendency \& Dispersion }\end{array}$ \\
\hline Descriptive Statistics \& & $\begin{array}{l}\text { Measures of, Central Tendency } \\
\text { Economic Equations }\end{array}$ \\
$\begin{array}{l}\text { \& Dispersion and Price Elasticity } \\
\text { of Demand }\end{array}$ \\
\hline
\end{tabular}

\section{Results \& Discussion}

\section{Results}

\section{Consumption Patterns of the Sample}

The consumption patterns of the sample, both before and after the tariff revision, were analyzed using SPSS. The results obtained from the overall analysis, prior to break down of the data set according to the blocks of consumption are depicted in Table 2.

Table 2: Statistical Analysis of Overall Consumption Patterns

\begin{tabular}{lll}
\hline Statistical Measure & \multicolumn{1}{c}{$\begin{array}{c}\text { Before Tariff } \\
\text { Revision }\end{array}$} & \multicolumn{1}{c}{$\begin{array}{c}\text { After Tariff } \\
\text { Revision }\end{array}$} \\
\hline Mean & 22.71 units & 19.60 units \\
Median & 23 units & 19 units \\
Mode & 23 units & 18 units \\
Standard Deviation & 9.4255 & 10.4084 \\
Variance & 88.841 & 108.335 \\
Range & 50 units & 51 units \\
Minimum & 2 units & 0 units \\
Maximum & 52 units & 51 units \\
\hline
\end{tabular}


Thereafter, the consumption patterns were further analyzed decomposing them into the blocks of consumption. The results obtained are depicted in Table 3.

Table 3: Statistical Analysis of Block-wise Consumption

\begin{tabular}{|c|c|c|c|c|c|c|c|}
\hline \multirow[b]{2}{*}{$\begin{array}{l}\text { No } \\
\text { tat } \\
\text { ion }\end{array}$} & \multirow[b]{2}{*}{$\begin{array}{c}\text { Block of } \\
\text { Consum } \\
\text { ption }\end{array}$} & \multicolumn{3}{|c|}{ Before Tariff Revision } & \multicolumn{3}{|c|}{ After Tariff Revision } \\
\hline & & $\begin{array}{l}\text { Frequ } \\
\text { ency }\end{array}$ & $\begin{array}{c}\text { Percen } \\
\text { tage }\end{array}$ & $\begin{array}{l}\text { Cumula } \\
\text { tive } \\
\text { Percent } \\
\text { age }\end{array}$ & $\begin{array}{c}\text { Frequ } \\
\text { ency }\end{array}$ & $\begin{array}{l}\text { Perce } \\
\text { ntage }\end{array}$ & $\begin{array}{c}\text { Cumul } \\
\text { ative } \\
\text { Percen } \\
\text { tage }\end{array}$ \\
\hline 1 & $00-05$ & 3 & 1.5 & 1.5 & 21 & 10.8 & 10.8 \\
\hline 2 & 06-10 & 16 & 8.2 & 9.8 & 17 & 8.8 & 19.6 \\
\hline 3 & $11-15$ & 28 & 14.4 & 24.2 & 27 & 13.9 & 33.5 \\
\hline 4 & $16-20$ & 35 & 18.0 & 42.3 & 41 & 21.1 & 54.6 \\
\hline 5 & $21-25$ & 49 & 25.3 & 67.5 & 30 & 15.5 & 70.1 \\
\hline 6 & $26-30$ & 24 & 12.4 & 79.9 & 25 & 12.9 & 83.0 \\
\hline 7 & $31-40$ & 30 & 15.5 & 95.4 & 29 & 14.9 & 97.9 \\
\hline 8 & $41-50$ & 8 & 4.1 & 99.5 & 3 & 1.5 & 99.5 \\
\hline 9 & $51-75$ & 1 & 0.5 & 100.0 & 1 & 0.5 & 100.0 \\
\hline 10 & Over 75 & 0 & 0 & 100.0 & 0 & 0 & 100.0 \\
\hline & Total & 194 & 100.0 & - & 194 & 100.0 & - \\
\hline
\end{tabular}

\section{Determination of Change in Price}

The tariff structures for domestic consumers, implemented by NWSDB, before and after the tariff revision in October 2012, were obtained. Although the tariff levied by NWSDB consists of both fixed and variable components, thus, is a two-part tariff scheme, only the variable component, the unit rate, had been changed, during the tariff revision in October 2012, while the fixed component has remained unchanged. The two tariff structures are depicted in Table 4.

Table 4: Tariff Structure Before and After the Revision

\begin{tabular}{ccccc}
\hline \multirow{2}{*}{$\begin{array}{c}\text { Block of } \\
\text { Consumption }\end{array}$} & $\begin{array}{c}\text { Usage } \\
\text { Charge Rs. } \\
\text { / Unit }\end{array}$ & $\begin{array}{c}\text { Monthly } \\
\text { Service } \\
\text { Charge Rs. }\end{array}$ & $\begin{array}{c}\text { Usage } \\
\text { Charge Rs. } \\
\text { / Unit }\end{array}$ & $\begin{array}{c}\text { Monthly } \\
\text { Service } \\
\text { Charge } \\
\text { Rs. }\end{array}$ \\
\hline $00-05$ & 3.00 & 50.00 & 12.00 & 50.00 \\
$06-10$ & 7.00 & 65.00 & 16.00 & 65.00 \\
\hline
\end{tabular}




\begin{tabular}{crrrr}
$11-15$ & 15.00 & 70.00 & 20.00 & 70.00 \\
$16-20$ & 30.00 & 80.00 & 40.00 & 80.00 \\
$21-25$ & 50.00 & 100.00 & 58.00 & 100.00 \\
$26-30$ & 75.00 & 200.00 & 88.00 & 200.00 \\
$31-40$ & 90.00 & 400.00 & 105.00 & 400.00 \\
$41-50$ & 105.00 & 650.00 & 120.00 & 650.00 \\
$51-75$ & 110.00 & $1,000.00$ & 130.00 & $1,000.00$ \\
Over 75 & 120.00 & $1,600.00$ & 140.00 & $1,600.00$ \\
\hline
\end{tabular}

As there was no change in the monthly service charge (the fixed component), the usage charge (the variable component) will only affect the price elasticity of demand. Prior to calculation of it, the change in price as a percentage was calculated, and they are depicted in Table 5 , for each block of consumption.

Table 5: Percentage Change in Price

\begin{tabular}{crrr}
\hline $\begin{array}{c}\text { Block of } \\
\text { Consumption }\end{array}$ & $\begin{array}{c}\text { Usage Charge - } \\
\text { Before } \\
\text { Revision Rs. / } \\
\text { Unit }\end{array}$ & $\begin{array}{c}\text { Usage Charge - } \\
\text { After Revision } \\
\text { Rs. / Unit }\end{array}$ & $\begin{array}{c}\text { Percentage } \\
\text { Change in } \\
\text { Price }\end{array}$ \\
\hline $00-05$ & 3.00 & 12.00 & $300.00 \%$ \\
$06-10$ & 7.00 & 16.00 & $128.57 \%$ \\
$11-15$ & 15.00 & 20.00 & $33.34 \%$ \\
$16-20$ & 30.00 & 40.00 & $33.34 \%$ \\
$21-25$ & 50.00 & 58.00 & $16.00 \%$ \\
$26-30$ & 75.00 & 88.00 & $17.34 \%$ \\
$31-40$ & 90.00 & 105.00 & $16.67 \%$ \\
$41-50$ & 105.00 & 120.00 & $14.29 \%$ \\
$51-75$ & 110.00 & 130.00 & $18.18 \%$ \\
Over 75 & 120.00 & 140.00 & $16.67 \%$ \\
\hline
\end{tabular}

\section{Determination of Change in Consumption}

From the consumption data obtained from NWSDB, for the 200 consumers attached to area engineers' office at Fort, first, the average consumption of each consumer for a period of nine (09) months before and after the tariff revision was calculated. Thereafter, in order to prevent the impact of outliers on analysis, six (06) data items were removed.

After that, the remaining 194 data items on average consumption, before and after the tariff revision, were decomposed according to the 
blocks of consumption, and the percentage change in quantity was calculated.

\section{Determination of Price Elasticity of Demand}

After obtaining the percentage change in consumption, then, using the percentage change in prices, the Price Elasticity of Demand for each consumer, for each block of consumption was calculated.

Thereafter, for each block of consumption, the average Price Elasticity of Demand was calculated. In order to understand the deviation of the consumers from the mean, the standard deviation too was calculated. The results are depicted in Table 6.

Table 6: Block-wise Price Elasticity of Demand

\begin{tabular}{ccc}
\hline $\begin{array}{c}\text { Block of } \\
\text { Consumption }\end{array}$ & $\begin{array}{c}\text { Average Price } \\
\text { Elasticity of } \\
\text { Demand }\end{array}$ & $\begin{array}{c}\text { Standard } \\
\text { Deviation }\end{array}$ \\
\hline $00-05$ & -0.02 & 0.08 \\
$06-10$ & -0.08 & 0.26 \\
$11-15$ & -0.19 & 2.12 \\
$16-20$ & -0.51 & 1.56 \\
$21-25$ & -0.87 & 4.24 \\
$26-30$ & -0.87 & 2.32 \\
$31-40$ & -0.76 & 2.42 \\
$41-50$ & -0.32 & 1.47 \\
$51-75$ & -0.06 & 0.79 \\
\hline
\end{tabular}

Over 75

Average PED $=-0.41 \quad$ Standard Deviation among PEDs $=0.3519$ 


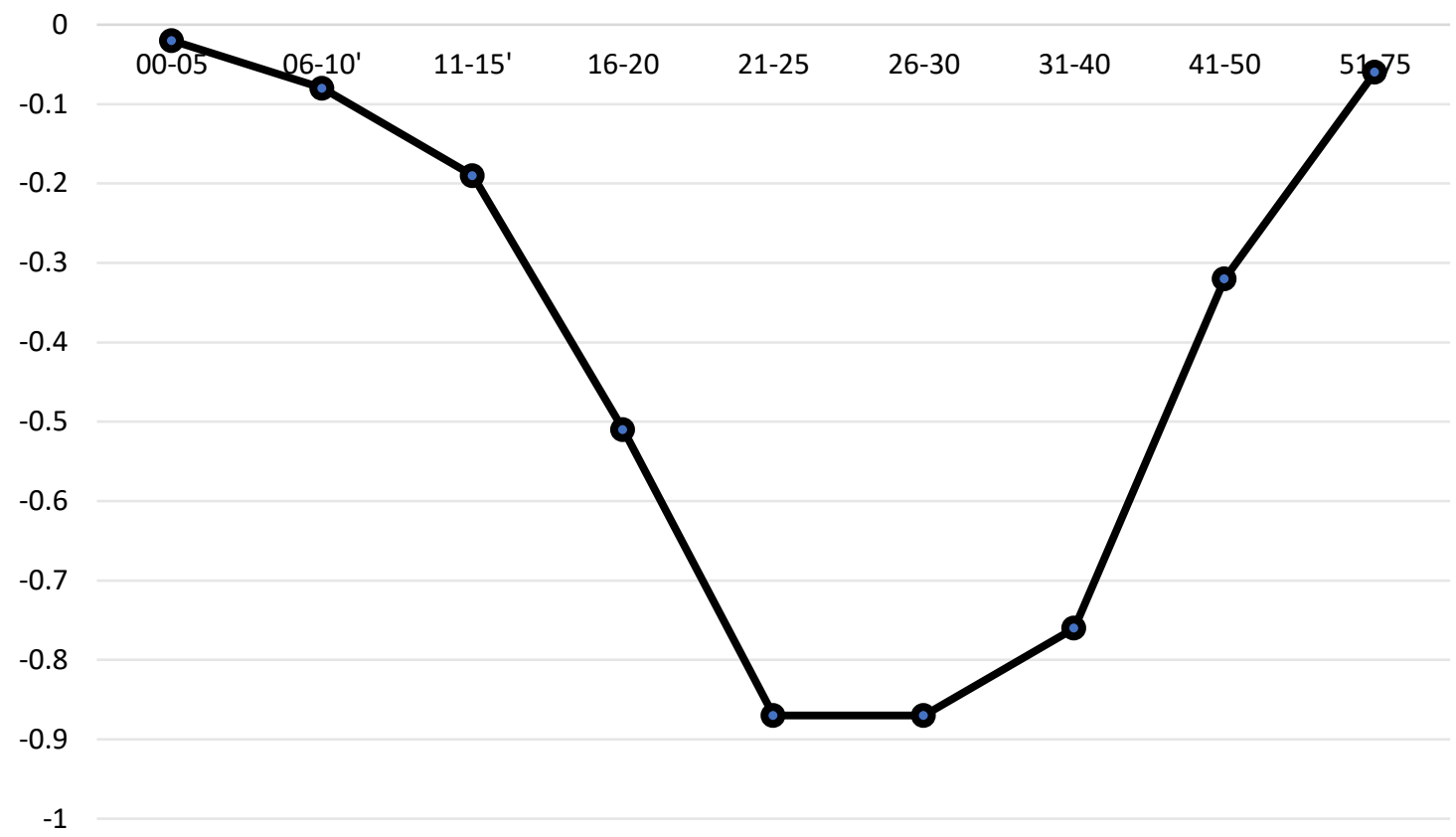

Figure 1: Block-wise Variation in Price Elasticity of Demand

\section{Results and Discussion}

\section{Overall Consumption}

According to the statistical analysis of overall consumption of the sample, Table 2, it is observed that with the revision in tariff, the mean consumption has reduced approximately by $14 \%$. Furthermore, the mode and median consumption have reduced. These, along with the measures of dispersion calculated, such as range, imply that the consumption of pipe-borne water in the Colombo city, is sensitive and responsive to the changes in prices, and thus, a Price Elasticity of Demand can be expected.

Moreover, according to Table 3, which has analyzed the consumption patterns of the sample according to the blocks of consumption, it is observed, that after the revision more consumers are concentrated at lower blocks. For an example, the increase in percentage of consumers consuming 00-20 units is $12.3 \%$, whereas the decrease in percentage of consumers consuming $21-50$ units too is $12.5 \%$. These two percentages being approximately equal implies the validity of the claims, that the demand for pipe-borne water is responsive to 
price and that it can be used as a tool to discourage wasteful consumption.

\section{Disparity among Blocks of Consumption}

As the demand for pipe-borne water is observed to be price-elastic, then, it was checked whether there was a disparity among the blocks of consumption with respect to Price Elasticity.

According to Table 6 and Figure 1, which depict the block-wise variation in Price Elasticity of Demand, it is observed that there is a significant variation in Price Elasticity of Demand. The Price Elasticity of Demand is lower at the first three and the last two blocks, and it is significantly high for the four blocks in the middle.

Thus, it can be inferred that there is a significant variation among the blocks of consumption with respect to Price Elasticity of Demand.

\section{More and Less Responsive Blocks of Consumption}

As observed in Table 6 and Figure 1, there is a significant variation in Price Elasticity of Demand among the blocks of consumption. The average Price Elasticity of Demand for the first three blocks being lower, along with the overall average consumption calculation support the fact, that the consumers have to essentially use up to 15 units, in order to satisfy their basic needs. However, the consumption of additional units up to a maximum of 40 units can be wasteful, as those blocks have a quite high price elasticity of demand. Thereafter, even the highest consumption is responsive to price; however, the responsiveness is still less than the four blocks in the middle.

Thus, it can be inferred that the first three and the last two blocks are less responsive to changes in price, while the four blocks in the middle are more responsive to the changes in price. This reestablishes the claim that wasteful consumption can be prevented via a revision of tariff.

\section{Conclusion}

For a number of reasons, including rapid urbanization, increase in population, climatic conditions accompanied by increased pollution 
and depletion of water sources, there exists a water problem in the Colombo city. This has ultimately resulted in several consequences, such as health and sanitation issues, water stress and threats to the financial sustainability of NWSDB.

Encouraging water conservation will be, thus, a pragmatic solution to reduce the magnitude of the problem. One way of achieving it and preserving economic efficiency related to the service has been identified as the revision of tariff structure. However, in an instance where an increase block tariff structure is employed by NWSDB, a uniform increase throughout the blocks would jeopardize the economic efficiency related to the service. Therefore, in the effort to implement an effective and acceptable tariff structure, assessment of Price Elasticity of Demand is an essential pre-condition to be satisfied. This study attempted to establish the Price Elasticity of Demand for the provision of water to the domestic consumers in the Colombo city.

In order to achieve the objectives of the study, the consumption patterns of 200 consumers, chosen from the Colombo city, after and before the last tariff revision in 2012, were assessed and the Price Elasticity Demand was calculated. The results showed that the consumers are responsive to the changes in price, or tariff, in the case of water, and a disparity among the different blocks of consumption with respect to Price Elasticity of Demand was observed. In the nine blocks of consumption considered, the first three blocks and the last two blocks were less responsive to changes in price, whereas the four blocks in the middle were more responsive to price. Therefore, it was observed that up to a maximum of 40 units the consumption can be wasteful and it can be prevented via a tariff revision.

This study has few implications on the policy making related to water tariff. It is that dependent on the motive of the tariff, the revision of unit rates for different blocks of consumption can be varied. If the motive is to preserve welfare of the society and economic efficiency and encourage conservation, then, the revision of unit rates for blocks of consumption, which are more responsive to price, could be made upward and higher. However, if the motive of the revision of tariff is to increase the overall revenue, then, irrespective of the blocks, for all blocks, the unit rates could be changed. Moreover, linking this 
change to the inflation index would be more realistic and socially acceptable.

Moreover, NWSDB, the main authority instrumental in providing pipe-borne water to the Colombo city, can utilize these findings to estimate the responsiveness of quantity consumed to the changes in price, and thereby revise the tariff structure in a more realistic and socially acceptable way. Furthermore, the methodology could be adopted to extend the study for all the areas where NWSDB is instrumental in the provision of water, to introduce a regional tariff structure, reflective of consumer needs in different regions, rather than keeping to the currently utilized, uniform tariff structure. Moreover, even for commercial, industrial and other sectors, this assessment could be extended to efficiently provide the service, with minimal financial burden.

Furthermore, the study attempted to establish the Price Elasticity of Demand for a utility. While there were other methods, such as contingent valuation method, it could be proved that the time series analysis too is possible in this effort, following other similar studies. Thus, this knowledge of methodology can be adopted in future studies. Moreover, the study could be extended to the whole country, as and when the requirement arises to study and analyze the responsiveness of consumers to changes in tariff, not only for pipeborne water, but also for other utilities.

\section{Acknowledgement}

Authors wish to acknowledge the support received from National Water Supply \& Drainage Board via provision of data required for the study.

\section{References}

Bandara, N. (2003). Water and wastewater related issues in Sri Lanka. Water Science Technology, 47(12), 305-312. Retrieved from https://www.ncbi.nlm.nih.gov/pubmed/12926703. 
Bishop, D. \& Weber, J. (1996). Impacts of demand reduction on water utilities. Denver, CO: AWWA Research Foundation and American Water Works Association.

Boland, J. J., \& Whittington, D. (2000). Water tariff design in developing countries: disadvantages of increasing block tariffs (IBTs) and advantages of uniform price with rebate (UPR) designs. World Bank Water and Sanitation Program, Washington, DC, 37.

Boyes, W. \& Melvin, M. (2012). Microeconomics (1st ed.). Mason, OH: South-Western Cengage Learning.

Brannon, M., Dikhanov, Y., Djayeola, B., Hamadeh, N., MouyeloKatoula, M., \& Rissanen, M. et al. (2017). Operational guidelines and procedures for measuring the real size of the world economy. World Bank. Retrieved 17 January 2017, from http://documents.worldbank.org/curated/en/95810146818 4461971/Operational-guidelines-and-procedures-formeasuring-the-real-size-of-the-world-economy

Brears, R. (2015). Urban Water Security (1st ed.). John Wiley \& Sons.

Cabral, L. (2005). Introduction to industrial organization. Cambridge, Mass.: The Mit Press.

Cairncross, S. \& Kinnear, J. (1992). Elasticity of demand for water in Khartoum, Sudan. Social Science \& Medicine, 34(2), 183-189. http://dx.doi.org/10.1016/0277-9536 (92)90095-8.

Conley, B. (1967). Price elasticity of the demand for water in Southern California. The Annals of Regional Science, 1(1), 180-189. http://dx.doi.org/10.1007/bf01290019

Creswell, J., \& Plano Clark, V. (2011). Designing and conducting mixed methods research. Los Angeles: Sage.

Department of Census \& Statistics (DOCS). (2015). Statistical Newsletter.Retrievedfromhttp://www.statistics.gov.lk/Newsle tters/DCSB-PUB-2015-01.pdf

Desalination research and the water problem. (1962) (1st ed.).

Washington. 
Fan, M. (2016). Sri Lanka's Water Supply and Sanitation Sector: Achievements and A Way Forward(1st ed.). Asian Development Bank. Retrieved from https://www.adb.org/sites/default/files/publication/161289 / south-asia-wp-035.pdf

Feenstra, R. \& Taylor, A. (2008). International macroeconomics (1st ed.). New York: Worth Publishers.

Fernando, G. (2014). Challenges of Sustainable Water Supply for Cities: Lessons Learnt in Reduction of Non-revenue Water in Colombo, Sri Lanka. In SAITM RSEA. Colombo: SAITM. Retrieved from http://www.saitm.edu.lk/fac_of_eng/RSEA/ SAITM_RSEA_2014/imagenesweb/33.pdf

Gamini, P. (2015). Challenges in the Water Sector and Wastewater Sector (1st ed.). Retrieved from http:/ /www.waterboard.lk/ web/images/contents/media/articles/challenges_in_the_wat er_sector_and_waste_water_sector.pdf

Howe, C. (1982). The impact of price on residential water demand: Some new insights. Water Resources Research, 18(4), 713716. http://dx.doi.org/10.1029/wr018i004p00713

Katzman, M. (1977). Income and Price Elasticities of Demand for Water in Developing Countries. Journal of the American Water Resources Association, 13(1), 47-55. http://dx.doi.org/10.1111/j.1752-1688.1977.tb01989.x

Letchumanamohan, S. (2014). Solution for national water supply \& drainage board customers' problems in Colombo city (Master). University of Moratuwa.

Mills, G. (2002). Retail pricing strategies and market power. Carlton South, Vic.: Melbourne University Press.

Ministry of Megapolis and Western Development. (2017). Megapolis.gov.lk. Retrieved 17 January 2017, from http://megapolis.gov.lk 
National Water Supply and Drainage Board. (2017). Waterboard.lk. Retrieved 17 January 2017, from http://www.waterboard.1k/

Niels, G., Jenkins, H., \& Kavanagh, J. (2011). Economics for competition lawyers. New York, NY: Oxford Unviersity Press.

Olmstead, S., Michael Hanemann, W., \& Stavins, R. (2007). Water demand under alternative price structures. Journal of Environmental Economics and Management, 54(2), 181-198. http://dx.doi.org/10.1016/j.jeem.2007.03.002

Phlips, L. (1999). The economics of price discrimination. Cambridge [u.a.]: Cambridge Univ. Press.

Proceedings of the First International Symposium on Water Desalination, United States. Office of Saline Water. (1966). In First International Symposium on Water Desalination. U.S. Department of Interior, Office of Saline Water, 1966. Retrieved from https:// books.google.1k/books?id=omErAAAAYAAJ\&pg $=$ PP8\&lpg=PP8\&dq $=\% 22$ desalination $\% 2$ Bresearch $\% 2$ Band $\% 2$ Bthe\%2Bwater\%2Bproblem\%22\&source=bl\&ots=SPYqPsfZWr \&sig=Sz_LlUCYRigse3SybMOhZBDrp_E\&hl=en\&sa=X\&ved $=0$ ahUKEwj32Jiw7t7YAhUBHJQKHX7oAS0Q6AEIJzAA

Rajput, R. (2007). A textbook of power system engineering (1st ed.). New Delhi: Laxmi Publications.

Rogers, P., De Silva, R., \& Bhatia, R. (2002). Water is an economic good: How to use prices to promote equity, efficiency, and sustainability. Water policy, 4(1), 1-17.

Sri Lanka to limit water supply, Colombo consumption up - Lanka Business Online. (2017). Lankabusinessonline.com. Retrieved 27 January 2017, from http://www.lankabusinessonline .com/sri-lanka-to-limit-water-supply-colombo-consumptionup/

Stevens, T., Miller, J., \& Willis, C. (1992). Effect of Price Structure on Residential Water Demand. Journal of the American Water Resources Association, 28(4), 681-685. http://dx.doi.org/10.1111/j.1752-1688.1992.tb01489.x 
Thomas, J. \& Syme, G. (1988). Estimating residential price elasticity of demand for water: A contingent valuation approach. Water Resources Research, 24(11), 1847-1857. http://dx.doi.org/10.1029/wr024i011p01847

Warakapitiya, K. \& Shankar, R. (2017). Monster water tanks for the few choke off supply for the many | The Sunday Times Sri Lanka. Sundaytimes.lk. Retrieved 27 January 2017, from http:/ /www.sundaytimes.1k/161009/news/monster-watertanks-for-the-few-choke-off-supply-for-the-many211785.html

Young, R. (1973). Price elasticity of demand for municipal water: A case study of Tucson, Arizona. Water Resources Research, 9(4),1068-1072. http://dx.doi.org/10.1029/wr009i004p01068 